\title{
A literatura infantil e xuvenil en Galicia. Cara a unha restruturación do sistema literario
}

\author{
Hértor Mera Herbello \\ (UNED) \\ Aos meus alumnos do colexio Don Bosco de Vigo (curso \\ 2004-2005). Por estaren sempre turrando do carro dos so- \\ ños e da ilusión.
}

\section{LIMIAR}

Abordar a literatura infantil e xuvenil no ámbito galego implica comezar a ter en conta varias cuestións que, noutros casos, non se deberían nin mencionar. Mais, este é un caso especial que se ve influido por unha serie de circunstancias históricas e sociais que determinan a súa evolución. Para sermos conscientes da importancia da nosa literatura infantil e xuvenil e o porqué da súa aparición e case inmediata eclosión, teremos que facer antes unha pequena descrición do sistema literario galego en cada periodo histórico. Explicar as causas desta literatura cunhas características tan de seu desde a inmediatez non nos dá unha visión global do que supón o fenómeno.

O noso traballo dedicará especial atención á narrativa infantil e xuvenil dos últimos 25 anos. Mais, nunha literatura minorizada coma a nosa, abordar certos temas sen un mínimo de perspectiva condena calquera reflexión que se faga á parcialidade. Para sabermos o que significa hoxendía a narrativa de índole infantil e xuvenil, antes hai que amosar a presenza que tivo no decorrer histórico da nosa literatura e matizar e clarexar o papel, por mínimo que fose, que tivo en cada momento.

É por iso que, cando falamos de literatura adicada aos máis novos, e non digamos xa no que atinxe á narrativa, temos que facer unha distinción inicial. Saber diferenciar os textos adicados a nenos con exclusividade e dentro da intencionalidade e conciencia dun proxecto - talmente ocorre na actualidade dende as diferentes publicacións pensadas para eles-, e os textos que, sen conciencia nin sequera do concepto «infantil» poden resultar agradables para os máis novos. Estes últimos son textos destinados a adultos que, pola súa compoñente fantástica fanse accesibles aos nenos. Dende a Idade Media ata practicamente o século XIX teremos que ter en conta este tipo de literatura «adaptable» á sensibilidade e ao mundo infantl dende un mundo creado para o lecer dos adultos. 


\section{CONTEXTUALIZACIÓN}

Vaiamos aos comezos da nosa literatura para ir debullando os elementos que a foron conformando ao longo dos tempos.

Xa na Idade Media, cunha literatura en periodo de esplendor e ben recoñecida na Península e en todos os ámbitos literarios cultos da Europa do medievo, os xéneros literarios que se daban naquel momento non foron cultivados de igual xeito polos nosos primeiros trobadores e xograis. Había unha clara diferenciación xenérica dependendo de cal era o territorio do que se tratase.

Así, mentres en Galicia literaturizabamos baixo as pautas da Arte de Trovar e só, e non o perdamos de vista, se compoñía poesía lírica - profana e relixiosa- nos nosos lindes, en Castela, por exemplo, independentemente de que moitos queiran demostrar o contrario sen textos nos que se apoiar, só se cultivaba a poesía épica. Non foi ata o século XV cando aparecen os primeiros textos en prosa na nosa lingua e, en todo caso, non deixaban de seren traducións dos textos prosísticos casteláns.

Quere dicir todo isto que, mesmo en épocas de prestixio para a nosa literatura, sen ningún elemento externo que interferira de xeito palpable nela, o noso sistema literario víase reducido no ámbito xenérico, aínda que ese xénero literario fose referencia no resto de Europa.

Agora ben, sendo certo que no podemos falar dunha literatura infantil neste período, si que podemos facer ver cales serían os textos ou composicións coñecidas a través da oralidade que puideran chamar máis a atención ao público de menor idade. Ten moito fundamento pensar que as lendas de tradición oral, as historias cunha compoñente fantástica que se narrasen por aquel tempo, serían adecuadas para o goce da rapazallada. Ademais desta literatura popular, os nenos terían ocasión de contemplar as representacións teatrais de tipo relixioso. As obras de carácter «culto» chegarían a eles por medio da trasmisión oral e entre os temas e textos máis difundidos que puidesen interesar poderíamos citar: Os «Miragres de Santiago», As "Cantigas de Santa María» e historias bíblicas e haxiográficas. É dicir, os motivos literarios do momento, os que máis auxe tivesen e estivesen en boca dunha maioría da poboación chegarían a eles coma contos que se lles ían relatando.

Esta elaboración literaria nin se pode ter por intencionada para este sector concreto da poboación que eran os nenos - lembremos que o concepto de infancia non estaba asimilado naqueles tempos-, nin se pode ter como elementos dunha literatura de xénero. Simplemente era unha literatura de adultos que lle acaía moi ben aos nenos polas circunstancias temáticas.

Pouco e pouco, este periodo de esplendor literario esvaécese, e chegan moi malos tempos para a nosa literatura. De todos son coñecidos os Séculos Escuros da literatura galega que, e isto non é casualidade, coinciden co chamado Século de Ouro da literatura en lingua castelá.

Galicia e Castela vense enfrontados entre o século XIV e o XV nunha serie de Guerras dinásticas nas que os galegos sempre se posicionan a favor do bando 
que acabaría sendo derrotado, polo que o bando vencedor foi impoñendo unhas políticas colonizadoras, opresoras e antigalegas que, engordiño, botarían abaixo a moral e o afoutamento da nobreza e o campesiñado galego.

Foron os Reis Católicos os máis severos represores das reivindicacións da nobreza galega. Xa antes Henrique de Trastámara, impuxera a súa vontade contra a nobreza galega partidaria do seu adversario Don Pedro I.

Este comportamento reaccionario contra as clases dirixentes galegas tiveron o seu máximo apoxeo despois das dúas revoltas Irmandiñas (1431 e 1467). A derrota foi de tal magnitude que a sociedade galega se viu ensarillada nun contexto político e social tan adverso que o desánimo e a resignación impuxéronse a calquera outro intento reivindicatorio. As forzas desapareceron e, a posteriori, os galegos víronse sometidos á mercede dos Reis Católicos.

Todos estes acontecementos foron o preámbulo ao período máis negro para a literatura de nós, pois o parón na produción de textos literarios ou non literarios foi de tres séculos, conservando aínda moi pouquiños textos da época que fixeron ben axeitado a denominación de Séculos Escuros para este periodo. A meirande parte dos textos literarios seguen sendo textos poéticos seguindo a tradición dos nosos trobadores en canto á preferencia polo xénero, sen ser estas composicións merecentes dunha gran estima literaria, senón histórica. As únicas manifestacións literarias que podemos estimar interesantes para un oínte novo eran os vilancicos de Nadal e a lírica de circunstancias, de índole popular, na que se salientaba a figura de algún heroe como pode ser o caso do Mariscal Pedro Pardo de Cela ou algún acontecemento como puido ser o Saqueo de Cangas polos piratas turcos-berberiscos. Máis alá nada. Só foi a partir do Século XVIII coa aparición dos homes ilustrados como Frei Martiño Sarmiento ou o Padre Feixó cando comeza Galicia a albiscar unha raiola de luz.

O século XIX é o do Rexurdimento. Destacan os literatos pola magnífica elaboración duns textos poéticos de primeirísima importancia. Rosalía de Castro, Curros Enríquez e Eduardo Pondal son os tres grandes poetas deste periodo e son merecentes dunha gran atención por parte dos estudosos que os teñen por tres dos grandes poetas de toda a nosa historia literaria. Así as cousas, no Rexurdimento da literatura galega xa comezan a publicarse textos narrativos, dramáticos e préstaselle moita atención á literatura popular, aínda que a súa importancia e seguimento non se acheguen nin de lonxe aos poemarios dos tres grandes.

Os textos conservados con tema de interese para a infancia son: os vilancicos dos cantores mindonienses de Nadal, os poemas adicados ao recén nado príncipe Afonsiño, fillo da raíña Isabel II, as fábulas ao estilo la Fontaine de Francisco Mirás e Amador Montenegro Saavedra — as súas Fábulas galaicocastellanas pode ser considerada a primeira obra galega destinada especificamente para os lectores máis novos-e os poemas inseridos nos grandes poemarios de Rosalía, Curros, Pondal, Xoán Manuel Pintos e os contos de autores como Heraclio Pérez Placer, Xosé Bieito Amado e outros. Tamén houbo espazo para o teatro infantil grazas á autoría de Manuel Lago Fernández, Arcebispo de Santiago dentro da liña adoutrinadora tan típica nalgunhas ordes relixiosas especialmente motivadas polo xénero teatral. 
No primeiro terzo do século xx chega unha eclosión literaria para Galicia que se manifesta, fundamentalmente na renovación dos contidos e das formas para os nosos textos. Destacan neste periodo os escritores das Irmandades da Fala, encabezados pola sabedoría de Ramón Cabanillas, verdadeiro sucesor de Curros na súa poesía máis reivindicativa, e os escritores da Xeración Nós. Tamén, aínda que con menos forza, se exceptuamos a figura escintilante de Manuel Antonio, estarán os escritores de vangarda, rachadores coa tradición decimonónica.

A Xeración Nós, grupo de intelectuais que pretenden poñer a Galicia no ronsel cultural e literario da Europa do momento, tivo unha grandísima importancia para Galicia. Estes homes son os primeiros en ter un proxecto real do que debe ser a cultura e a literatura galega rexeitando para ese proxecto o ruralismo e literatura costumista que tanto se prodigaba dende o século anterior. Vexamos que os literatos xa non compoñen dende a simple intuición deixándose levar polo que predomina en cada momento na «literatura en lingua galega». Facemos especial fincapé no sintagma entrecomillado por non teren os máis dos escritores galegos a literatura en lingua vernácula como unha literatura culta, alta. Había, ao igual que na Idade Media, unha diferenciación, aínda que no caso da literatura costumista non era nada favorable para os ntereses da literatura minorizada.

Otero Pedrayo, Afonso Daniel Castelao, Florentino Cuevillas co maxisterio de Vicente Risco, son os encargados de dar pulo a unha nova literatura galega. Xa non ven cara a atrás, non collen referentes literarios anacrónicos. O que fan é europeizar a nosa literatura. Eran homes extremadamente cultos e postos ao día do que se estaba facendo alén Pireneos. Concebían a cultura e a literatura galega dende unha perspectiva máis atlantista, europeísta e isto crea necesidades. Crea necesidades, para comezar, coa concepción das súas obras. As novelas - fixémonos que xa non predomina o lirismo na súa expresión literaria- son moi influenciadas por autores europeos e americanos como Joyce, Faulkner, Dos Passos... polo que as técnicas narrativas desenvólvense nestes eidos. Nas súas novelas xa ambientadas en contorno urbano, con personaxes cun perfil intelectual moi claro, os elementos desas novelas permitirán exprimir as súas teimas desde unha introspectiva onde o monólogo interior, entre outras técnicas de novo, collen sitio e novos pulos na literatura galega.

Ademais, dentro desta corrente de culturización e de achegamento ás culturas importantes a nivel internacional, os de Nós cultivan e inauguran o ensaio como xénero fundamental para dar saída aos coñecementos teóricos dos que son posuidores. Vemos como o sistema literario se amolda ás necesidades históricas, sociais e culturais.

A poesía é cultivada dende unha óptica xebradora do que se estaba a facer. Fóra dos autores como Noriega Varela ou Leiras Pulpeiro que a principios do século XX aínda estaban con poesía de tipo costumista sen saíren de aí, as novas xeracións como Amado Carballo ou Manuel Antonio, seguidos a distancia no que é a concepción poética por Euxenio Montes, Álvaro Cunqueiro e Fermín Bouza Brey, dan á luz unhas obras, nos primeiros, propiamente vangardistas, nos demais, a medio camiño entre a tradición e a vangarda como pode ser no caso do Neotrobadorismo. O primeiro terzo do século Xx é unha revolución para as no- 
sas letras que viña a confirmar o proceso imparable que nos anunciara o Rexurdimento.

Salientamos deste período os proxectos literarios no eido infantil xa plenamente conscientes de seu. Pasamos, tal como explicábamos máis arriba, dunha literatura destinada para adultos que, polo seu tema de índole fantástica e marabillosa, podía interesar ao neno, pero sen unha intencionalidade de destinatario explícito, ás obras, aínda que sexan poucas en cantidade e de calidade discutible, cun destinatario infantil xa predeterminado, cun mínimo proxecto de facer literatura para nenos e nenas. Son obras que saen de xeito esporádico e, como todo o que comeza, non supoñen ningún fito nin salto cualitativo no conxunto da historia deste tipo de literatura.

$\mathrm{O}$ adianto real que apreciamos nos tempo das Irmandades e da Xeración Nós é a concenciación de teren que facer unha literatura especializada para crear novos e bos lectores na nosa lingua. Todo este movemento artéllase a través das asociación de índole pedagóxica que veñen xa do século XIX e dos que Risco é un importante expoñente.

Deste período destacamos a narrativa de autores como Carré Aldao, Correa Calderón, Díaz Baliño, Leandro Carré, Cotarelo Valledor, García Barros entre outros. A poesía e o teatro infantil tamén serían cultivados (Amado Carballo, Filgueira Valverde...). Mesmo chegaron a saír dous números dunha revista de especialidade chamada "As Roladas», subtitulada «Folla dos rapaciños galegos» $\mathrm{e}$ que saíu no ano 1922. Arredor do proxecto estiveron persoeiros como O Marqués de Figueroa, Leonardo Rodríguez, Portela Valladares, Risco, Castelao, Fernández Flórez...

Mais, coa chegada da Guerra Civil volve haber un parón. Todo o que se adiantara, todo o que se conseguira queda en nada pola chegada ao poder do Réxime franquista que renegaba de calquera manifestación culta nas linguas minorizadas do Estado. E dicimos «manifestacións cultas» porque o que si permitía eran unhas pseudomanifestacións folclóricas onde non había cabida para máis, polo que os primeiros poemarios que se van publicando a comezos do periodo franquista son poemarios costumistas que representan unha volta atrás no proceso dinamizador da nosa cultura.

É a partir da década do 50, coa aparición da Editorial Galaxia cando, con moitos problemas coa censura, van saíndo novas publicacións de interese na nosa lingua. Xunto a outras editorias como Bibliófilos Gallegos, Monterrei ou a Colección Benito Soto, Galaxia colle o relevo dos membros de Nós, algún deles como é Otero está tamén arredor do proxecto, e retoma a concepción dunha literatura galega baseada nun proxecto claro e cuns referentes evidentes nas figuras que estaban arredor da editorial. Merecería outro tratamento a literatura que se fixo na diáspora americana na que, entre outros, estiveron exiliados Castelao, Seoane ou Lorenzo Varela.

En narrativa, nesta década dos 50 destacaron Carballo Calero, Blanco Amor, Ánxel Fole e, como non, Álvaro Cunqueiro.

O ensaio cobra, outra volta, como na época da Xeración Nós, unha importancia capital no proxecto. 
A finais dos 50 e na década dos 60 prodúcese un novo fenómeno literario na nosa narrativa. Nos anceios de equiparar a nosa literatura coas literaturas de alén as nosas fronteiras comeza unha nova andaina que é a chamada Nova Narrativa Galega que é, independentemente dos matices que se poidan subliñar, claramente debedora do Noveau Roman francés. Escritores que se poden ncluír neste movemento serían: Suárez Llanos, Rodríguez Mourullo, María Xosé Queizán, Xosé Luís Méndez Ferrín, Xohana Torres ou Carlos Casares.

$\mathrm{Na}$ década dos 70 dáse unha nova viraxe na narrativa galega. En momentos de efervescencia política e social coa realidade do posfranquismo, os autores dan a luz unhas obras que, posiblemente, estivesen preparadas dende antes esperando o momento oportuno para veren a luz. Hai unha necesidade de volver á narrativa tradicional ademais dunha corrente renovadora que serían os seguintes (2001: 370-371): Realismo ruralista e etnográfico; narrativa memorialista; narrativa histórica; realismo sociolóxico; narrativa alegórico-social; narrativa de xénero; narrativa experimental. Algúns dos narradores máis importantes desta época serían Paco Martín,Martínez Oca, Casares, Xavier Alcalá, Lois Diéguez, Alfredo Conde, entre outros.

$\mathrm{Na}$ década dos oitenta e ata a actualidade vemos como a narrativa consolídase no noso sistema literario e desbanca a poesía.

Agora, o que prima, é a diversidade temática. Os autores non se ven tan coutados polos diversos movementos literarios ou narratolóxicos. Hai unha nova situación política e editorial que permite unha maior tiraxe nos libros e un aumento dos títulos. Ademais, isto vai acompañado dunha liberdade absoluta na escolla dos contidos e das maneiras de expresalos. Así, tanto textos declaradamente tradicionais, xúntanse con outros de xeira nidiamente máis experimentalista.

Axuda moito neste proceso a educación obrigatoria en galego que provoca que moitos destes libros sexan de lectura obrigatoria nas escolas, instituto ou mesmo nas universidades. Hai un achegamento e unha mellor distribución da obra en galego que chega con máis facilidade á xente, cousa esta, non tan doada ata a data pola competencia case exclusiva da literatura en castelán.

E aquí é onde entra a literatura infantil e xuvenil neste xogo de axustes e reaxustes no sistema literario. A relación causa-consecuencia favorece desta volta á literatura destinada tamén para os máis novos, pois ata o de agora, non se tiña sentido a necesidade de explorar este campo totalmente á mercede á literatura en lingua castelá. De seguido imos ver a xénese deste proceso.

\section{IRRUPCIÓN DA NARRATIVA INFANTIL E XUVENIL NO SISTEMA LITERARIO. XÉNESE E PERIODIZACIÓN}

Se ata o de agora non podíamos falar dunha literatura infantil e xuvenil per se, senón que máis ben do que habería que falar é dunha literatura de circunstancias aproveitable para nenos - bardante as excepcións feitas de obra esporádicas como a de Amador Montenegro Saavedra ou principios de proxecto como o de Nós- a partir da década dos 60 xa si podemos comezar a falar dunha in- 
tencionalidade máis clara do que sería un novo espazo para a literatura e a narrativa infantil e xuvenil no sistema literario galego.

Este proceso integrador pasa por varias fases que, como veremos, cunha celeridade sorprendente, aínda que con atrancos polo camiño, chega á consolidación da que goza hoxendía.

$\mathrm{Na}$ década dos 60 a produción e distribución de libros era complexa. Aínda co labor de editoriais como Galaxia que, xa dende o ano 50, estaba facendo un labor encomiable ofrecendo literatura galega nuns eidos que ata esa data a ditadura non permitía publicar. Artellar unha saída para estes libros era dificilísimo. Primeiro: pola propia oposición gobernamental a que saísen libros desta índole en galego por seren posibles elementos educativos no ensino. Segundo: pola propia inercia dunha sociedade que non entendía a importancia que para o conxunto da comunidade tiñan este tipo de iniciativas.

Con todo, a editorial Galaxia lanzouse no ano 61 á coedición coa editorial catalana La Galera. Sen a asociación con esta editorial albiscábase imposible tal aventura que, a pesar do interesante que se presentaba, finou aos poucos títulos publicados pola falta de vendas que facían imposible un proxecto tan ambicioso. A pesar de teren en mente a publicación dun nutrido número de libros, soamente se chegaron a publicar sete. Hai que ter en conta que estas coedicións eran os mesmos libros que saían en Cataluña, pero traducidos ao galego.

O seguinte paso dado pola mesma editorial foi sacar unha colección propia. Esta, como se pode intuír polo fracaso anterior, había ser unha colección moito máis sinxela na súa edición. Non obstante, ten o valor estimable de ser a primeira colección de literatura infantil galega de seu, pois xa introducen autores autóctonos. O león e o paxaro rebelde de Bernardino Graña, ou A galiña azul de Carlos Casares, son a día de hoxe obras clásicas que xurdiron daquela colección promovida por Galaxia.

O seguinte fito en importancia desta década é a aparición do Premio de literatura infantil e xuvenil convocado pola Asociación Cultural O Facho en 1968. Esta iniciativa anima a moitos escritores a crear para nenos. Son moitos os autores de relevancia que saíron deste certame.

Ao tempo, autores como Manuel María, Neira Vilas ou María Victoria Moreno comezan a publicar as súas primeiras achegas.

A comezos dos 70 continúase con este tortuoso percorrido abrindo novos camiños. É de destacar que do ano 72 data a tradución que Carlos Casares fai d'O Principiño. Tamén aparece un voceiro de todo o fenómeno que se está a producir neste aspecto na nosa literatura. A revista infantil Vagalume é un proxecto interesantísimo no que se dá renda solta a diferentes actividades didacticopedagóxicas a través dos contos infantís, dos cómics... A revista era mensual e tiña unha distribución moi localizada a través das parroquias e dos colexios.

Unha nova etapa poderíamos situala a partir da aprobación do Decreto de Bilingüismo que faría que a lingua galega entrase nos colexios como lingua oficial e obrigatoria. $\mathrm{O}$ marco legal que interesa como acobillo da produción da literatura galega en xeral e da infantil e xuvenil en particular, é a Constitución Es- 
pañola que daría os diferentes Estatutos de Autonomía que, no caso galego, albergaría unha Lei de Normalización Lingüística.

Este novo e peculiar proceso ten como consecuencia inmediata a necesidade de posuír para os diferentes niveis de ensino obrigatorio unha serie de material bibliográfico que fixo que as editoriais existentes se puxesen a traballar nel, mesmo provoucou a fundación doutras editoriais como Xerais e Sotelo Blanco.

Por fin un modelo claro de edición do libro para a xuventude se estaba perfilando.Ventábanse novos horizontes nun sistema literario galego que se estaba refacendo a si mesmo chegando a cotas que nunca antes imaxianara.

Pero para contar con textos precísanse autores. Nace o que se deu en chamar a figura do «escritor-mestre». Profesionais do ensino que son conscientes do momento e da importancia de estar aí para poder ofrecer libros en galego que se saían dos textos que tradicionalmente se ofrecían en castelán. Hai que ir enchendo ocos para compertir co resto das literaturas peninsulares. Iso si, con desigual sorte.

A década dos 90 foi, sen dúbida a da consolidación. A marxinalidade do libro infantil e xuvenil tende a desaparecer acadando un protagonismo que moi poucos aventuraban. Para as editoriais xa non se trata de experiencias aventureiras cun próposito firme, pero con poucas posibilidades de seguir cara a adiante. Xa hai un receptor claro a través dos colexios que lles preparan os lectores máis novos como consumidores frecuentes da súa literatura. Isto conleva unha especialización que non só se ve nas numerosas colección específicas que van xurdindo, senón que tamén nos numerosos premios e na calidade in crescendo dos textos. Xa pasou a época de literatura de circunstancias para cubrir ocos. $\mathrm{O}$ escritor especialízase máis e é máis consciente e mellor coñecedor do lector ao que vai dirixida a súa obra. Gañan en profesionalidade e mesturan o seu talento coas táboas e o bo facer dunha maior preparación.

A guinda da torta achegaríaa a aparición da editorial Kalandraka no ano 1999. Unha editorial dedicada única e exclusivamente á literatura infantil e xuvenil en galego. Dende os seus maioritarios textos de creación ata os ensaios sobre o fenómeno literario que nos ocupa, Kalandraka só ten ollos para o lector máis novo. As publicacións desta editorial caracterízanse por ser coñecidas no mundo enteiro pola súa extraordinaria calidade que a levou a ser condecorada con premios de primeirísimo nivel como poden ser o Premio Nacional de Ilustración.

Kalandraka rompeu moldes dende a súa aparición non só polo moi estimable da calidade literaria das súas publicacións, ou exquisito gusto das ilustracións espectaculares que adornan os seus libros. Ademais, Kalandraka é pioneira no eido da distribución meténdose e competindo en mercados nos que, ata o de ago$\mathrm{ra}$, ningunha editorial galega, e moito menos co seu fondo infanto-xuvenil, se arriscaría a meterse. Dende Corea a USA, pasando por Rusia ou infinidade de países latinoamericanos sen mencionar o feito de que os libros da editorial saen en todas as linguas peninsulares, Kalandraka estende o seu produto ata lugares insospeitados para unha editorial como esta e máis tendo en conta de que a lin- 
gua de partida, o sistema literario do que falamos, son claramente minorizados.

Feita esta breve exposición, agora si, poderemos entender con maior claridade a razón pola cal é importante ter en conta as diferentes situacións que esta literatura tan especial ten no sistema literario galego. De ser marxinal, un subproduto de escaso interese editorial, nas mans duns cantos iniciados conscientes da importancia do que tiñan entre mans, pasamos a ver que estamos nun momento no que a nosa literatura para os máis novos é pioneira alén fronteiras. $\mathrm{O}$ interese que nos últimos tempos amosaron por ela grandes editoriais de ámbito español, de ámbito internacional baixo a maxistral mediación da editorial $\mathrm{Ka}$ landraka e o cada vez maior espazo que lle adica a crítica literaria do país, demostra que estamos ante un produto creativo que tira e é fundamental no sistema literario de nós. A día de hoxe é impensable unha literatura onde se prescindise deste tipo de libros. É máis, gran parte dos beneficios das editoriais -con esta afirmación non queremos facer pensar que son cuantosísimos- parten das súas coleccións especializadas en nenos e mozos.

Por todo isto, a literatura infantil e xuvenil en Galicia é importantísima e fundamental no noso contorno e aínda moi importante no resto do Estado español.

\section{UN FENÓMENO CONCRETO: A NARRATIVA}

Para comezar este apartado delimitaremos o noso campo de acción dende o ano 79 en diante. Seguíndomos a Cobas Brenlla (1991:82-83), a Fernández Paz (1998: 44) e (1999: 42) e conxugando as súas propostas, a narrativa en galego tería uns eixes temáticos máis ou menos definidos:

- Lendas de tradición popular.

- Novelas de adolescentes.

- Realismo máxico.

- Histórica.

- Ciencia-ficción.

- Novela policiaca.

- Textos didácticos.

O primeiro dos eixes temáticos neste novo proceso de narrativa galega dedicada exclusivamente a un público infante é case que de obrigado cumprimento. Nunha Galicia de fonda raigame lendaria, máxica e mitolóxica, os contos de tradición oral son unha fonte de narracións inesgotable. En calquera parroquia do país podemos atopar innumerables mitos e lendas que aínda perviven entre a poboación e que nos poden amosar fantasías de estimable aproveitamento para contárllelo aos nosos pequechos. Aquí adiviñamos unha dobre funcionalidade: a escrita en si do texto literario que, neste caso sería máis ben unha readaptación ou recreación do conto ou lenda orixinal e, por outro lado a seguranza de ter pasado a historia ou lenda a unha xeración posterior en moitos casos descoñecedores deste mundo de ensoño que é a Galicia máxica de substrato mitolóxico, lendario e contístico. 
Destacamos dentro deste apartado textos clásicos como son Arnoia, Arnoia de Xosé Luís Méndez Ferrín publicado no ano 85, ou o título publicado no mesmo ano por María Xosé Queizán $O$ segredo da pedra figueira. Nos últimos tempos están tendo moito éxito a través da colección Cabalo Buligán as sagas que están sacando o triunvirato composto por Antonio Reigosa, Xosé Miranda e Xoán Ramiro Cuba. Xa sexan os contos fantásticos ou os Contos marabillosos, Contos de maxia, Contos de animais e demais, estes tres escritores están marcando época no que ao traballo de campo e recreación dese material se refire. Son un referente indispensable e vastísimo na adaptación de lendas e contos de tradición popular.

Proliferaron moitísimo ao longo destes anos as novelas en que os protagonistas son adolescentes que se ven involucrados nalgunha aventura. Desde os grupos de amigos que dende unha vida absolutamente normal, propia de calquera adolescente, vense na necesidade de resolver algún misterio, ata os protagonistas onde se perfila unha caracterización do personaxe intimista -independentemente da trama - agromando os sentimentos, teimas, problemas e inquedanzas dos rapaces, este tipo de narrativa adoita ter moito éxito polo grao de identificación que pode ter o lector adolescente cos personaxes da historia. Un exemplo case extremo e de moitísimo interese para facernos unha idea do que se está a expor é a novela de Francisco Castro Un bosque cheo de faias. Por pioneiras neste tipo de temas poderíamos ter as obras de María Victoria Moreno, Leonardo e os fontaneiros; $O$ misterio das badaladas de X. P. Docampo ou o Premio Lazarillo de 1999 A banda sen futuro de Marilar Aleixandre. Mención aparte merece $O$ prognóstico da lúa de Marga Romero que ten a particularidade de meterse no mundo das drogas e a violencia dende unha visión moi rachadora e atraente para o lector.

A seguinte corrente que nos ocupa é aquela en que a diferenciación entre os termos fantástico, marabilloso e realidade é fundamental para recoñecer os procesos que os levan a conxuntarse nun estilo moi peculiar na súa postulación, pois parte do principio literario do «estrañamento»; tan pertinente en literatura. Seguíndomos a Todorov ' consideramos que o «marabilloso" é aquilo que ten a súa orixe e explicación en algo sobrenatural. Á súa vez, o «fantástico» é aquilo que deixa en dúbidas sobre a súa orixe e explicación. É dicir, o lector non alcanza a discernir se a explicación a determinado acontecemento vén dado por un elemento sobrenatural que provoca a circunstancia dubidosa ou se a explicación, máis alá de andrómenas de tipo sobrenatural, é de de índole racional.

O fantástico, pero sobre todo a compoñente marabillosa pódese mesturar coa realidade dende, por exemplo unha ambientación realista, cuns personaxes e mesmo un tempo dentro do común que, en principio non fai pensar ao lector que teña que haber ningún tipo de incidencia que poida trocar esta aparente normalidade na narración. Mais, de súpeto, no medio deste contexto e este contorno tan cotián aparece un feito de índole fantástica ou marabillosa que lle dá un novo cariz á lectura e que incluso pode provocar certa estrañeza no lector.

\footnotetext{
1 TODOROv: Introducción a la literatura fantástica, Buenos Aires. Ed. Tiempo contemporáneo.
} 
Este tipo de técnica narrativa ten certa tradición na literatura galega. Vén do que para moitos foi gran mestre na arte de narrar que non é outro que o mindoniense Álvaro Cunqueiro. Con esta afirmación non pretendemos encadrar a obra de Cunqueiro dentro da literatura infantil e xuvenil. Obras como Se o vello Simbad volvese ás illas aconséllanos non facelo pola complexidade que pode atopar un neno e mesmo un adolescente na súa lectura. Agora ben, estes elementos aos que nos referimos son condimentos que moitos dos seus discípulos souberon colleitar moi ben para dar forma e esencia ás súas obras, estas si, destinadas xa ao lector estrela que nos preocupa dentro deste campo.

Paco Martín, X. A. Perozo, Carlos Casares ou Darío Xohán Cabana son algún dos seus continuadores.

A novela de tema histórico ten certa presenza. Neste apartado metemos as obras que corresponderían ás diferentes mitoloxías das que se nutriu a nosa literatura con especial atención a aquelas que cobren o tema da Bretaña; e as que recrean a vida de personaxes reais ao redor de feitos históricos consumados (se é que na historiografía se pode empregar o adxectivo consumado para referírmonos a eses feitos).

En primeiro termo, no que se refire ao tema da Bretaña, temos obras como Irmán Rei Artur de Carlos Reigosa.

Fóra da mitoloxía propiamente dita, temos obras que recrean a vida dalgún personaxe histórico, facilmente recoñecible para calquera lector de lírica medieval, como é As flores do meu amigo, novela moi interesante de Rafael Fernández Lorenzo onde ten como protagonista ao trobador Paio Gómez Charinho.

Son de interese tamén, entre outras cousas polo curioso tratamento que reciben por parte dos seus autores, obras como Grandes feitos e lides de Carlomagno de Inma e Manuel García Sendón, que non é outra cousa que unha recreación dos milagres de Santiago.

A ciencia ficción tamén ten cabida na nosa literatura, pero quizais sexa máis presente por obras traducidas doutros autores estranxeiros que por produción propia. Aí esta a recente Crónicas marcianas como exemplo máis claro de por onde vanos tiros neste eido temático. X. Agulla e María García Yáñez son autores galegos que lle adicaron atención a este xénero, así como Miguel Vázquez Freire co seu Proxecto pomba dourada (1987). Citaremos dentro deste subxénero obras de moito éxito no seu momento como foron $A$ sombra cazadora de Suso de Toro, Perigo vexetal, As flores radioactivas de Agustín Fernández Paz ou Mutacións xenéticas de Fina Casalderrey. Máis recentemente aparece Ariadna de Xosé Miranda, unha novela na que se recrea un mundo estraño no que se dan circunstancias de certo inquietantes, pero que mesmo se cobren dunha sensibilidade na relación entre personaxes que nos fan salientar esta obriña certamente estimable.

A novela policial en Galicia vén da man de Carlos Reigosa ao que se lle pode atribuír tal mérito, mais no que se refire á literatura estritamente xuvenil temos autores de grande éxito e moi seguidos como son Roque Morteiro ou, o que é o mesmo, Xelís de Toro co seu xa clásico Seis cordas e un corazón, X. P Do- 
campo, Manuel Rivas, Manuel Forcadela e Ramiro Fonte. Todos eles son os responsables, respectivamente, de títulos coma $A$ chave das noces, Todo ben, Sangue sobre a neve ou Cómplice. Cristina Frasié fai unha sátira da novela policial co seu Mambo negro (1991)

Se facemos unha clasificación xeral do que serían os textos didácticos, aquí entrarían se non toda a produción susceptible de analizar, case. Podería parecer unha parvada dicir que os textos destinados a estas idades teñen sentenza didáctica ou que pretender ter unha mensaxe determinada para os mozos, xa sexa no que atinxe aos valores e principios de índole universal, xa sexa na preparación do lector dun determinado tema de interese no ámbito da educación.

Acontece que, tendo todos estes textos en maior ou menor grao por textos didácticos, uns levan a mensaxe implícita predominando un tema determinado sobre esa ensinanza inserida no texto e outros están pensados e concebidos única e exclusivamente para ser canle de información sobre un acontecemento en concreto.

Sobre estes últimos temos un exemplos moi recentes e clarificadores en toda a literatura para nenos que saíu a raíz da catástrofe do Prestige, que é literatura destinada a ensinarlles aos nenos unha realidade concreta, moi determinante para o seu contorno e da que os nenos deben ser coñecedores. Nin que dicir ten, fóra de publicacións tan especiais como é esta última, traballos como os destinados a divulgar diferentes aspectos mitolóxicos e lendarios, que entrarían dentro deste grupo. Citamos aquí a obra Druídas, Deuses e heroes da mitoloxía celta da autoría de Anne Ross. As biografías de persoeiros como Castelao ou Ánxel Fole tamén teñen este carácter divulgativo coa clara finalidade de potenciar canto antes mellor esa cultura xeral que calquera neno debe ir adquirindo por estar na idade de poder absorver sen dificultade todo canto lle caía nas mans.

Quizais sexa na vertente divulgativa onde se creasen as polémicas máis interesantes dentro da nova narrativa emerxente. Moitos autores, estudosos ou profesores, de marcada ideoloxía nacionalista ou, tinguidos simplemente dun sentimento galeguista que derivaba nunha clara preocupación polo país, criticaron duramente no seu momento o feito de que, presuntamente, non se aproveitase máis a eclosión e demanda desta literatura para expresar e incidir nun discurso de concienciación nacional. Vían na literatura e na narrativa xuvenil unha oportunidade inmellorable para facer fincapé nesta eiva identitaria nas mocedades galegas. Ben, este tipo de discurso é moi discutible, pois o simple feito de estar levando adiante unha narrativa en lingua galega xa supón un adianto inestimable no que a identificación cunha lingua, unha cultura e un país se refire.

\section{DA DÉCADA DOS 90 Á ACTUALIDADE: A CONSOLIDACIÓN AO ABEIRO DO REALISMO NOVELÍSTICO}

Xa fomos adiantando obras que se poderían inserir neste apartado dentro da clasificación máis xeral coa que vimos de diseccionar a narrativa galega ao logo destes case vinte e cinco anos de rodaxe. 
Agora, coa claridade de ver que os 90 foron os anos da consolidación e encumbramento, imos facer un breve repaso ás causas e ás obras que máis incidiron nesta realidade.

Para comezarmos, debemos ter en conta un feito que nos parece fundamental, independentemente do bo facer das editoriais a través das cada vez máis consolidadas coleccións e premios literarios que lle dan moito prestixio á produción que nos ocupa. A ampliación do ensino obrigatorio dos catorce aos dezaseis anos. En tan tempranas idades dous anos seméllanos un camiño moi longo onde a aprendizaxe, coñecementos e inquedanzas dos rapaces dan un chimpo cualitativo e cuantitativo de moita consideración.

Comeza un mundo no que os amigos e amigas, as novas relacións que se poden dar entre eles e elas, o descubrimento doutros mundos que poden ser mesmo perigosos (droga, violencia...) están á orde do día, polo que se fai necesario adecuar unha literatura que cubra e que faga aprender a estes rapaces sobre a problemática social e individual que os incomoda, oprime e nalgúns casos, mesmo os condiciona e marca para o resto das súas vidas.

É neste campo de cultivo onde se fan necesarias, e adoitan ter moita repercusión, as novelas de índole realista. A conflitividade, violencia, drogas, iniciación nas relacións afectivas e no sexo, forman parte, e os escritores fan moi ben en non enganarse, do construto vital da adolescencia e a literatura en xeral, e a narrativa xuvenil en particular, teñen que estar aí, para que, polo menos, no campo dos soños, estas novas inquedanzas na rapazallada non queden ao socairo.

O realismo que se ve nestas obras non se reduce, así a todo, aos problemas máis cotiáns da adolescencia máis sensible aos acontecementos antes comentados, senón que tamén hai que ter en conta a literatura destinada a un lector máis novo que, sen ter aínda nada que ver con este tipo de situacións, si ten un mundo propio onde, máis alá da súa maior inocencia, ten que ofrecérselle un tipo de narrativa onde se vexan identificados co que se lles conte.

Esta tendencia dos 90 é filla das circunstancias - non esquezamos que a nosa perspectiva inicial para este artigo é a readaptación desta narrativa dentro do sistema literario galego-, mais non chega eclipsar outras vertentes xa pescudadas e tratadas máis arriba.

Nesta liña temos unha noveliña xa convertida en clásica polos milleiros de lectores e lectoras que a encumbraron como tal que amosa moi ben este realismo para rapaces máis novos sen chegar á drasticidade da que falábamos. Trece anos de Branca de Agustín Fernández Paz é a tal noveliña que temos en mente. Ademais, para nenos e nenas aínda máis pequenos hai unha serie de material que se preocupa, fundamentalmente, do tratamento do contorno de seu, de maneira que procuren recoñecelo, valoralo e coidalo nun intento de educación polo respecto que é moi frecuente na nosa narrativa infantil.

Dentro do xénero máis cruamente realista, destacamos dúas novelas xa mencionadas anteriormente: Un bosque cheo de faias de Francisco Castro que toca, para moitos con grande valentía, a problemática dos rapaces e rapazas atraídos por grupos neonazis e moi violentos. $\mathrm{Na}$ outra banda, na que toca o pro- 
blema da violencia e da droga como punto luminoso fundamental, está $O$ prognóstico da lúa de Marga Romero. Son de moito interese e de moito éxito entre os adolescentes que inzan os nosos colexios e institutos obras como as que de seguido imos citar:

- Flores negras de Rafael Lema (Sotelo Blanco).

- Días de desterro de Xavier López Rodríguez (Xerais).

- Todo a cen de Jaureguízar (Sotelo Blanco).

- Anxos en tempos de chuvia de Miguel Vázquez Freire (Xerais).

- A banda sen futuro de Marilar Aleixandre (Xerais).

- A recortada de An Alfaya (Xerais).

Todas elas reflicten un interese moi concreto pola plasmación duns mundos e duns problemas onde a marxinalidade, propia dunha sociedade en pleno periodo de crise profunda dá arfadas e pide auxilio desesperadamente.

Pensemos que para facer este tipo de literatura o autor/a ten que poñerse na pel de rapaces e rapazas de $13,14,15,16$ anos. Teñen que meterse nas súas vivencas e intentar expoñelas do xeito máis crible posible, polo que hai que ter un coñecemento importante do que acontece no mundo. Coidamos que este realismo ao servizo da adolescencia dá moito xogo pola pluridimensionalidade de problemas, intereses e temas que nos achega a xuventude.

Mais, non só son os autores e autoras deste tipo de literatura os que se amosan interesados nesta literatura tan especial e específica, tamén as editoriais, pola súa conta, independentemente dos orixinais autóctonos que as nutren, engaden o seu gran de area sacando do prelo outras novelas ao xeito de autores estranxeiros e con certo interese para publicar dende Galicia. aí está a tradución feita por María Reimóndez de Ionqui, novela de Melvin burgess que, dende o ámbito da tradución, escenifica moi ben o tipo de xénero que as editoriais están importando para os lectores adolescentes. Sexo, droga, violencia, marxinación, problemas familiares serios, embarazos non desexados... todos estes ingredentes son de común aparición na literatura xuvenil-realista que predomina na década dos 90 ata a actualidade.

Con todo, dentro desta vizosa e rica narrativa, non é o realismo, por moita trascendencia que poida ter nos últimos tempo, a única temática que se afronta dende o país. A narrativa galega xuvenil está chea de matices dependendo da iniciativa do autor ou autora que non só está preparado para procurar achegar un texto axeitado para os seus moi especiais lectores, senón que, ademais, e moi afortunadamente, dende Galicia apréciase unha iniciativa moi pausible pola orixinalidade. Poderíamos encadrar todas as obras narrativas que queiramos dentro de subxéneros e temas do máis variopinto como medida e mal menor para facer un achegamento ao coñecemento da mesma, pero non seria honesto facelo sen considerar que esta técnica e puramente orientadora, xa que moitos textos achegan novas pescudas no ámbito técnico e no ámbito temático.

Así, consideramos oportuno mencionar as obras dedicadas ás historias de aventuras, ou dende outras perspectivas temáticas, adobiadas por unha contex- 
tualización histórica tan documentada que o lector pode quedar abraiado do traballo de documentación e o empeño amosado polo autor para sacar á luz tal obra. Destacamos neste eido de orixinalidade e traballo documentadísimo a novela $O$ armiño dorme de Xosé Neira Cruz que, dentro da colección Costa Oeste de Galaxia, acabará sendo coa perspectiva do tempo unha das máis estimables creacións narrativas do noso contorno literario.

A narrativa de feitura fantástica segue o seu desenvolvemento neste periodo culminante. Hai dous planos fundamentais. Un continuísta co que ata ese momento se viña facendo en Galicia no que respecta a este tipo de literatura e o outro máis acorde cunha tendencia máis xeralizada no conxunto da narrativa universal.

O primeiro destes planos ao que nos referimos é o xa cultivado por autores como Xosé Luís Méndez Ferrín, entre outros, onde a imaxinación brota arredor de mundos máxicos e míticos onde os heroes fan das súas fazañas o tema central das obras deste tipo e onde a materia da Bretaña, co Rei Artur, a raíña Xenebra e todos os cabaleiros da famosa Táboa Redonda, son protagonsitas. obras:

Destacamos dentro deste tipo de tendencia na nosa narrativa as seguintes

- As aventuras de Breogán Folgueira de Darío Xohán Cabana (Xerais).

- O castrón de ouro de Darío Xohán Cabana (SM).

- O país durminte de Xabier P. Docampo (Xerais).

O segundo dos planos ao que nos referíamos sería unha narrativa fantástica onde os acontecementos futuros terán especial atención. Nestas obras especúlase coa realidade da sociedade no futuro. E unha narrativa que na súa esencia conecta moi ben c'Un mundo feliz de Adouls Huxley.

Destacamos como obras máis interesantes:

- A sombra cazadora de Suso de Toro (Xerais).

- O asasino invisible de Xosé Durán (Galaxia).

Nos últimos tempos os relatos de misterio ou terror ao xeito de H.P. Lovecraft están moi ben representados con obras como a de Agustín Fernández Paz, Tres pasos polo misterio ou Cando petan na porta pola noite de Xabier P. Docampo.

Así poderíamos seguir ata chegar ás obras humorísticas, os relatos curtos e demais tendencias que agroman da diversidade literaria que presenta a nosa narrtiva galega.

Non obstante, ao non termos o ánimo de facer deste artigo un extenso catálogo de tendencias e obras, quedamos co fundamental. O espazo acadado pola narrativa galega no sistema literario galego que a fai ser un dos máis preciados baluartes do sistema editorial, ademais do máis prezado tesouro de ensoño para os nosos lectores primeirizos, ademais de futuros lectores que han levar unha boa preparación a pouco que teñan ánimo de inicairse na narrativa e na literatura en xeral adecuada a súa idade. 


\section{CONCLUSIÓNS}

Vistos xa, de xeito moi resumido, tanto a contextualización do que é a nosa narrativa destinada a rapaces, como a clasificación, entendemos que pola súa natureza, discutible en por si, chegamos ao momento de facer unha serie de consideracións finais a modo de reflexión.

Quedou claro que a aparición da narrativa infantil e xuvenil en Galicia foi tardía por circunstancias alleas do feito estritamente literario, pero que afectan moitísimo ao mesmo de xeito que incluso o poderían facer desaparecer. Referímonos aos condicionamentos sociais, culturais, políticos e económicos que determinaron considerablemente a aparición desta literatura.

Só cando se comezan a dar as circunstancias idóneas para que poida nacer esta literatura comeza a facelo moi timidamente e co tempo vaise consolidando ata o punto de chegar a un grao de ebulición tal que poderíamos dicir que en moi pouco tempo revolucionou o panorama literario galego.

Os fitos históricos aos que nos referimos máis arriba condicionaron certamente esta nova situación da narrativa que nos ocupa creando novas necesidades que faran saír do agocho aos escritores, primeiro case que «amateur», despois máis preparados na realidade da mocidade, que crearán un corpus literario de importancia, dándolle a volta a todo canto nos tiña acostumados a literatura galega ao longo da súa historia.

A iniciativa lectoescritora destes novos cultivadores literarios fará que - sendo moitos deles escritores noutros xéneros - reconsideren as técnicas narrativas, os puntos de vista e mesmo que se teñan que mergullar nun elenco de valores, sentimentos e inquedanzas que ata o momento non tiveran que expresar dentro do que é a actividade creadora. E aquí entra, ao noso modo de ver, unha das grandezas desta narrativa rachadora de vez no contexto literario galego. Novos lectores, novas perspectivas, novas técnicas, novas visións... literatura anovada.

En canto ao que atinxe a estas reflexións, entraríamos no aspecto xa comentado do discurso nacional e ideolóxico. Lembremos que hai persoas que critican o feito de que os autores de literatura infantil e xuvenil non se comprometen con certas máximas que entenden que deberían ser canalizadas a través dos libros destinados aos máis novos. Sen metérmonos no feito de se isto se chega a facer ou non, ou se se fixo nunha porcentaxe máis ou menos importante, e coa tranquilidade de sabermos que fóra de calquera outra consideración temática, a literatura galega xuvenil existe, o certo é que, o que ninguén pode negar é que os postulamentos teñen que ser totalmente diferentes ao que se fai na narrativa entendida para adultos. Poderíamos pensar que esta narrativa, en moitos casos, estivese escravizada por unha serie de traumas e fobias de índole histórica, política e social que teñen que ver coa situación de Galicia. Mais, no caso do novo fenómeno literario que estoupa no noso país, aquel que está destinado para os máis novos, os camiños son ben outros. Dá a sensación que neste eido a narrativa está máis normalizada. Atopamos máis variedade temática e formal. Non está subxugada ao que vén dende fóra e inda por riba é referente alén as nosas fronteiras cun recoñecemento fóra do soñado por calquera outro xénero de nós. 
Estamos, pois, ante un fenómeno curioso pola súa adaptación ao sistema literario. Cuns comezos realmente difíciles e cun periodo de adaptación a marchas forzadas, nos últimos anos poñémonos á vangarda da literatura para rapaces. É un xénero este que saca a cabeza dentro do que é o groso do que se fai en Galicia.

Agora ben, máis que un fenómeno independente do resto de expresións literarias que adoitan facerse no país, a narrativa infantil-xuvenil o que fai é axudar a dar pulo ao noso sistema literario achegando novos lectores, novos escritores, novas visións e un vangardismo dende Galicia que aínda está por sorprender a moitos.

Sen botar as campás ao voo, non temos ningunha dúbida de que a saúde desta nosa narrativa é un facho crucial no proceso normalizador no conxunto do sistema literario. Pasou de ser arrastrado e subxugado pola gran poesía e narrativa para adultos a converterse en referente desta polo seu dinamismo e anovación. Insólita, pero feliz realidade dunha narrativa que está en primeiro termo na literatura estatal e internacional.

\section{BIBLIOGRAFÍA}

AGRA, María Jesús e Roig, Blanca-Ana (2004): A memoria das guerras na literatura infantil e xuvenil en lingua galega, Xerais, Vigo.

Agrelo Costas, Eulalia (1999): «O Facho e a literatura infantil e xuvenil galega», en Revista Galega de Literatura Infantil e Xuvenil Fadamorgana, n. ${ }^{\circ}$ 2, pp 38-41.

COSTAS BREnLle, Xulio (1991): Historia da literatura infantil e xuvenil galega, Edición de Autor, Santiago de Compostela.

Cuba, Reigosa e Miranda (1999): Diccionario dos seres míticos galegos, Xerais, Vigo.

FERNÁNDEZ, María Jesús (1999): «A década dos 90, consolidación e crecemento», en $R e$ vista Galega de Literatura Infantil e Xuvenil Fadamorgana, n. ${ }^{\circ}$ 2, pp 52-64.

Fernández Paz, Agustín (1999): A literatura infantil e xuvenil en galego, Xerais, Vigo.

FERnándeZ PAZ, Agustín (1999): «Os 80: tempo de abrir vieiros», en Revista Galega de Literatura Infantil e Xuvenil Fadamorgana, n. ${ }^{\circ}$ 2, pp 42-48.

HARguINDEY, Henrique e BARRIo, Maruxa (1994): Antoloxía do conto popular galego, Galaxia, Vigo.

Solla Varela, Calros: Almanaque de encantos. Mitoloxía da terra de Cerdedo. (Inédita).

RoIG RECHOU, Blanca Ana (1999): «Os primeiros pasos cara á formación do sistema literario infantil e xuvenil», en Revista Galega de Literatura Infantil e Xuvenil Fadamorgana, n. ${ }^{\circ} 2$, pp 28-37.

TODOROv: Introducción a la literatura fantástica. Buenos Aires. Ed. Tiempo contemporáneo 